\title{
Dwie kultury?
}

Niniejsza książka jest owocem wieloletniej współpracy dwóch ośrodków naukowych: Zakładu Literatury Francuskiej, Komparatystyki Literackiej i Badań nad Belgią Frankofońską Uniwersytetu im. Adama Mickiewicza w Poznaniu oraz Laboratoire Littérature, Savoirs et Arts Uniwersytetu im. Gustave’a Eiffla w Marne-la-Vallée. Zakłady te współpracowały od 2014 roku w ramach grantu Polonium „Nauki o życiu: wyobraźnia i dyskurs naukowy” oraz grantu „Formy życia, formy literatury", finansowanego przez Narodowy Program Rozwoju Humanistyki. Oba projekty, kierowane przez profesora Mirosława Lobę oraz profesor Gisèle Séginger, poświęcone były związkom literatury i nauk przyrodniczych w dziewiętnastowiecznej Francji.

Ta interdyscyplinarna tematyka badań wpisywała się w szerszy kontekst refleksji nad rozdźwiękiem między „dwiema kulturami”, humanistyczną i przyrodniczą, zdiagnozowanym przez Charlesa Percy'ego Snowa w głośnym wykładzie z 1959 roku. Według brytyjskiego uczonego, reprezentantów tych „dwóch kultur” cechować miały wzajemne uprzedzenia, niechęć i brak zrozumienia, co prowadzić miało do pogłębiającego się kryzysu wartości naukowych i społeczeństwa w ogóle ${ }^{1}$. Charles Percy Snow oskarżał humanistów o graniczący z ignorancją brak zainteresowania wiedzą przyrodniczą; ale też odwrotnie - u reprezentantów nauk ścisłych rozpoznawał obojętność wobec „kultury tradycyjnej”. Ten pogłębiający się dystans między dyscyplinami miał, jego zdaniem, nieuchronnie skutkować zubożeniem wyobraźni intelektualnej wiodącym do kryzysu nauki i kultury².

${ }^{1}$ Charles Percy Snow, „Wykład Rede’owski, 1959. Dwie kultury”, w: idem, Dwie kultury, tłum. Tadeusz Baszniak, Prószyński i S-ka, Warszawa 1999, s. 80.

2 Ibid., s. 86-89. 
Celem projektów naukowych realizowanych w ramach wspomnianej wyżej współpracy polsko-francuskiej była próba podjęcia dialogu z naukami przyrodniczymi z perspektywy historyczno-literackiej. Naszą ambicją było również wskazanie, że w dziewiętnastowiecznej Francji „dwie kultury”, tak odmienne w ujęciu Charlesa Percy'ego Snowa, pozostawały w bliskim dialogu. Jak stwierdzić można na podstawie rezultatów dotychczasowych badań z zakresu epistemokrytyki ${ }^{3}$, prowadzonych w różnych ośrodkach naukowych na świecie, w dziewiętnastym wieku dialog ten odbywał się dwukierunkowo: pisarze inspirowali się najnowszymi odkryciami nauk przyrodniczych, ale i naukowcy czerpali z kultury literackiej, świadomie wykorzystując retoryczne zabiegi, by wpływać na swoich odbiorców za pomocą języka. Jakość i intensywność tej wymiany tłumaczyć można z jednej strony faktem, że dziewiętnasty wiek był okresem, w którym nowoczesne dyscypliny naukowe (biologia, chemia, medycyna ${ }^{4}$ ) dopiero wyłaniały się ze wspólnego korzenia nauk filozoficznych i szukały języka swojej specjalizacji ${ }^{5}$. Z drugiej strony konsekwencje ideologiczne, filozoficzne i religijne wielkich debat naukowych dziewiętnastego wieku interesowały szeroką publiczność, inspirując zarówno Balzaca, Hugo, Flauberta, Micheleta czy Verne'a, ale i autorów mniej znanych, takich jak Nodier, Ballanche, Richepin, Mirbeau i Flammarion.

${ }^{3}$ Epistemokrytyka jest nurtem metodologii badań literackich, który skupia się na zagadnieniu transferu szeroko rozumianej wiedzy z zakresu nauk (przyrodniczych, fizycznych, społecznych) do literatury. Prace badawcze w tym nurcie ukazują się między innymi w czasopismach naukowych „Épistemocritique” oraz „Arts et savoirs”. Więcej na ten temat zob.: Michel Pierssens, Savoirs à l'œuvre: essai d'épistémocritique, Presses universitaires de Lille, Villeneuve d'Asq 1990.

${ }^{4} \mathrm{Na}$ ten temat zob. Gisèle Séginger, „Présentation. Penser et rêver le vivant”, w: Romantisme, nr 154, numer tematyczny „Le Vivant”, 2011, nr 4, s. 3-20 oraz rozdział „Biologia i literatura”, w: Gisèle Séginger, Barbara Łuczak, Mirosław Loba, Życie i nauki o życiu w literaturze francuskiej i polskiej w XIX wieku. Studia, Wydawnictwo UAM, Poznań 2021.

${ }^{5}$ Idea specjalizacji nauk nie jest akceptowana przez wszystkich dziewiętnastowiecznych filozofów. Jeszcze w 1863 roku Ernest Renan będzie postulował jedność nauki pozytywnej, przeciw specjalizacji. Na ten temat zob. Gisèle Séginger, „Biologia i literatura”, op. cit., s. 12. 
W niniejszym tomie skupiamy się na twórczym dialogu między reprezentantami nauk przyrodniczych i literatury na gruncie trzech zagadnień: biologicznego pochodzenia życia (biogenezy), pochodzenia człowieka (antropogenezy) oraz przyszłości form życia (palingenezy). Choć teorie samorództwa, kreacjonizmu i palingenezy zostały stopniowo wyparte przez inne paradygmaty naukowe, adekwatność tych sposobów opisu rozwoju życia na Ziemi była w dziewiętnastym wieku gorąco dyskutowana, a czasem i żarliwie broniona przez wielu naukowców. Pisarze z kolei nie mieli większych skrupułów, by korzystać z teorii przebrzmiałych, uznanych za fałszywe - jeśli tylko wykazywały potencjał literacki, inspirowały i pobudzały wyobraźnię, mogły stanowić przedmiot literatury. Zwycięskie paradygmaty ${ }^{6}$ - takie jak ewolucjonizm - również były przyswojone przez literaturę. Jak przekonamy się o tym w niniejszym tomie, francuska myśl ewolucjonistyczna była niezależnie rozwijana przez wielu naukowców na długo przed publikacją On the Origin of Species (1859), przez co nie da się jej zredukować jedynie do recepcji dzieł Karola Darwina.

Niniejsza książka ma pomóc przybliżyć polskiemu czytelnikowi te nieoczywiste związki między literaturą i przyrodoznawstwem w dziewiętnastym wieku.

${ }^{6}$ Pojęcie to pochodzi od Thomasa Kuhna, który zaproponował ujęcie historii nauki w kategoriach długiego trwania i rozwoju, przerywanego rewolucjami naukowymi prowadzącymi do zmiany paradygmatu (Thomas Kuhn, Struktura rewolucji naukowych, tłum. Justyna Nowotniak i Helena Ostromęcka, Fundacja Aletheia, Warszawa 2001). 